\title{
The Causal Effect of Media-Driven Political Interest on Political Attitudes and Behavior*
}

\author{
Daniel M. Butler ${ }^{1}$ and Ana L. De La O ${ }^{2}$ \\ Department of Political Science, Yale University, Nem Haven, CT 06520-8209, USA \\ 1daniel.butler@yale.edu \\ 2ana.delao@yale.edu
}

\begin{abstract}
This article considers the hypothesis that media-driven political interest shapes party identification, the timing of vote decisions, and electoral participation. To estimate the effect of media-driven political interest, we make a key distinction between political interest as a lifetime political orientation and political interest that rises and falls with the occurrence of noteworthy political events. We then exploit the shared media markets in Switzerland and its neighboring countries to overcome the otherwise crippling endogeneity problem and identify exogenous increases in Swiss citizens' self-reported political interest caused by the coverage of national elections in France, Germany, and Italy. We find that media-driven political interest increases the length of time individuals use to make their vote decisions, decreases partisanship, and increases self-reported and actual turnout.
\end{abstract}

* An earlier version of this paper has been presented at the 2008 Political Methodology Meeting. The authors wish to thank participants at that presentation as well as John Bullock, Greg Huber, Holger Kern, Ken Scheve, Jasjeet Sehkon, Jim Snyder, two anonymous reviewers, and the editors for their helpful comments. We take responsibility for any remaining errors.

Online Appendix available from: http://dx.doi.org/10.1561/100.00010041_app

Supplementary Material available from:

http://dx.doi.org/10.1561/100.00010041_supp

MS submitted 26 May 2010; final version received 8 November 2010

ISSN 1554-0626; DOI 10.1561/100.00010041

(C) 2011 D. M. Butler and A. L. De La O 
What is the effect of media-driven political interest on other political attitudes and behavior? Some suggest that political interest, which is typically defined as "a citizen's willingness to pay attention to political phenomena at the possible expense of other topics" (Lupia and Philpot, 2005: 1122), benefits democracy by increasing the voting electorate with participants who are less partisan and think more carefully about their choices (Verba et al. 1995; Mansbridge, 1999; Dalton, 2004, 2008). However, other studies conclude that the politically interested are more partisan, more ideologically extreme, and less open to persuasion (Berelson et al. 1954; Campbell et al. 1960; Gopoian and Hadjiharalambous, 1994).

It is unclear which, if any, of these conclusions best describes the effect of mediadriven political interest because most studies conceptualize political interest as a lifetime political orientation. Yet media-driven political interest rises and falls with the occurrence of politically relevant events. For example, Marcus and MacKuen (1993) suggest that increased levels of anxiety during the 1988 US presidential campaign led some voters to pay more attention to the campaign and rely less on partisan predispositions to make their vote choice. Lacy and Burden (1999) indicate that Ross Perot's entry into the 1992 US race grew the electorate by sparking the interest of new and less partisan voters. Benz and Stutzer (2004) suggest that the introduction of the Maastricht Treaty generated intense discussions among voters in countries that had a referendum. Finally, Zaller (1998) discusses how major scandals can shape short-tem political interest and in turn evaluations of political figures. Thus the political interest due to exposure to political content in the media seems to generate different political dynamics than the political interest that comes from, for example, being a member of certain groups (like a church or a political party).

Answering the question of how media-driven political interest shapes political attitudes and behavior is important because electoral turnout and other manifestations of political engagement are in decline across established democracies (Norris, 1999). Our results contribute to the debate about whether efforts designed to increase the political interest of voters through media outreach (e.g., Lupia and Philpot, 2005) are likely to help reverse the negative trend in political engagement.

Although there is a vast body of research on the persuasive and mobilizing effects of different media outlets, most of these studies focus on the media's role in providing information ${ }^{1}$ as opposed to increasing political interest. Exceptions to this rule include recent

1 Here too, the empirical record is mixed. Putnam (2000) argues that television erodes civic participation because televised entertainment substitutes activities that foster political engagement. Livingstone and Markham (2008) find a small negative correlation between watching television and the likelihood to take action on a public issue. Similarly, Gentzkow (2006) finds that in the US the increasing use of television in 1950-1970 reduced turnout in House elections. In contrast, Norris (1996) argues that the media has mobilizing effects because of the exposure to news. Along this line, Baum (2002) finds that even consumption of "soft news" (entertainment-oriented quasi-news media outlets) helps bridge the knowledge gap between the attentive and inattentive to politics. Finally, Snyder and Strömberg (forthcoming) find that an increase in newspapers' political coverage leads to increases in voters' information and turnout in US House elections. 
studies that find that media can influence political interest under some circumstances ${ }^{2}$ (Lupia and Philpot, 2005; Stromback and Shehata, 2010; Delli Carpini, 2004), which, in turn, can increase the likelihood of political participation (Martin, 2008).

Our own expectation is that media-driven political interest, because of the increased investment in time and attention dedicated to political matters, benefits democracy by causing voters (1) to take longer in making vote decisions in order to ensure that they use the best possible information (Meredith and Malhotra, 2010), (2) to become less partisan because they are willing to invest effort into understanding political matters and are therefore less likely to rely on partisan cues (Popkin, 1991; Sniderman et al., 1991), and (3) to become more likely to turn out to vote because they are more invested in the outcome and therefore place a higher consumption value on voting (Hinich, 1981; Aldrich, 1993).

One of the difficulties in testing these hypotheses is that the available data does not distinguish media-driven political interest that is malleable in the short term from political interest as a long-term orientation. However, even if we knew the level of media-driven political interest, it is still insufficient information to establish a causal relationship between media-driven interest in politics and other attitudes and behavior, since those interested in politics are usually unlike those uninterested in observable and unobservable ways. Thus, a comparison between these two groups conflates the effect of media-driven interest in politics with preexisting differences that lead some voters to be interested but not others (see discussion in Verba et al., 1995: 344).

We measure media-driven political interest and identify its causal effect by taking advantage of the Swiss media market. In Switzerland, citizens consume media emitted from and concerning the neighboring countries: France, Germany, and Italy. ${ }^{3}$ As a result of the shared media markets, Swiss voters are more likely to hear about the news of the neighboring country that corresponds to their preferred language. Therefore, for example, when an election occurs in Germany, German-speaking Swiss hear more about it than their French and Italian speaking counterparts. ${ }^{4}$ During the election and the time afterward, when the new government forms, the German media is filled with

2 In particular, Stromback and Shehata (2010) find that in Sweden exposure to public service broadcast news has a higher correlation with political interest compared to exposure to commercial news. Yet they also find that exposure to morning newspapers and exposure to tabloids correlate positively with political interest. Martin (2008) argues that negative news coverage of politically relevant social issues stimulates political participation by shaping citizens' awareness of collective problems and fostering interest in politics. Lupia and Philpot (2005) find that in a survey experiment respondents of all ages report greater political interest after viewing news-related websites that they rate as effective and efficient than they do after viewing other sites.

3 Switzerland has a total of four official languages: French, German, Italian, and Romansh. We do not use the Romansh speakers in the study, however they represent less than 0.5 percent of the Swiss population.

4 This empirical strategy follows the spirit of Ansolabehere, Snowberg and Snyder's (2006) study of the incumbency advantage in the US. They use the structure of media markets within states and across state boundaries and compare incumbent vote margins in media markets where content originates in the same state as media consumers versus vote margins where content originates out of state. 
more political content (though not Swiss-specific content), thus exogenously increasing the media-driven political interest of the Swiss citizens who speak the language of the country where the election took place. We use the timing of the most recent election in the major neighboring country corresponding to the language spoken by the citizen as an instrument for their media-driven political interest to exploit this exogenous variation. Using this research design, we find that media-driven political interest increases the length of time individuals use to make their vote decisions, decreases partisanship, and increases self-reported and actual turnout.

\section{DATA AND EMPIRICAL MODEL FOR THE INDIVIDUAL-LEVEL DATA}

We use data from the Swiss National Election Studies cumulative file (Fontana et al., n.d.) from the period 1971-2003, along with data that we collected on election timing in France, Germany, and Italy, to test the following hypotheses:

H1: Increasing citizens' media-driven political interest makes them less likely to say that they knew their vote choice all along.

$\mathrm{H} 2$ : Increasing citizens' media-driven political interest decreases their likelihood of identifying with a party.

H3: Increasing citizens' media-driven political interest increases the self-reported number of initiatives and referenda they vote on. ${ }^{5}$

For the binary outcomes we use Instrumental Variable (IV) probit models while we use two-stage least squares regression for the continuous outcome. In all cases the first-stage is an OLS regression that uses our instrumental variable, the log (months since election), to predict political interest. We also use cluster-robust standard errors (White, 1984; Arellano, 1987) where we cluster on the combination of the respondent's canton and the year they take the survey. The number of clusters varies between 164 and 189.

We code our primary independent variable, political interest, as a continuous variable ranging from 1 to 4 based on how respondents describe their own general level of interest in politics $(1=$ not interested at all, $2=$ rather not interested, $3=$ rather interested, and $4=$ very interested). ${ }^{6}$ Even though political interest measures respondents' general level of interest in politics, our instrumental variable research design captures the variation in political interest that is exogenously manipulated by changing levels of political content

5 In Switzerland, unlike other democracies, elections to the federal legislative chamber are of lesser importance than the frequent referenda voters face. This is in large part because the power-sharing agreement between the main parties precludes any change of government. For this reason we test whether political interest has a causal impact on electoral participation by looking at whether interest increases the number of referenda a respondent reports participating in during the year.

6 We also checked the results when coding political interest in a binary manner, using the dummy variable high level of political interest which takes a value of 1 for those indicating that they were either rather interested, or very interested in politics and a value of 0 for those who indicated that they were either not interested at all or rather not interested in politics. Those results lead to all of the same substantive conclusions that are presented here and can be found in the supplementary appendix. 
in news coverage (Dunning, 2008). In other words, our empirical tests look specifically at the effect of media-driven political interest.

Our instrument, $\log$ (months since election), is the natural $\log$ of the number of months since the most recent national legislative or presidential election in the major neighboring country ${ }^{7}$ - France, Germany, or Italy — corresponding to the language spoken by the respondent. ${ }^{8}$ We chose this instrument because Swiss citizens are consuming media emitted from and concerning the neighboring country where their primary language is spoken (we discuss this phenomenon in detail in the next section). Thus, when an election occurs in one of these major neighboring countries, the Swiss citizens who speak the same language are exposed to more political news content as the new government forms and implements new policies. Because of the mass media's well-documented agendasetting function (McCombs and Shaw, 1972), this increase in political coverage about the neighboring country should cause individuals to place more importance on politics and thereby cause them to become more interested in politics generally. The logarithmic transformation is meant to capture that the amount of political activity related to government change, and therefore the amount of political content in the news, drops off quickly after an election. ${ }^{9}$

Figure 1 illustrates the cross-sectional and time-series variation in our instrumental variable by graphing the average value of $\log$ (months since election) for each linguistic group for the election survey. As Figure 1 shows, the value of the instrument varies primarily between 1.5 (which roughly corresponds to 5 months since the last election) and 4 (which roughly corresponds to 55 months since the previous election).

For the study we focus on three outcomes. First, we use the self-reported timing of individuals' vote decisions in the federal election, which was asked in each of the surveys except 1975, to create a binary dependent variable, knew vote all along, that takes a value of 1 if they said that they "knew it all the time" and a value of 0 for any other valid

7 Appendix $\mathrm{B}$ of the supplementary appendix gives the timing of the elections in the neighboring countries.

8 We use the language that the survey was conducted in, as an indication of the respondent's preferred language. For the 1987 and 1991 surveys, when this information was not recorded, we use the respondent's linguistic region as coded by the Swiss Election Study as there is a 95 percent correspondence between respondents' linguistic region and the language of their interview in surveys when both are recorded. The Swiss Election Study also failed to record the month of each interview during the 1979, 1987, and 1995 election surveys. However, because the interviews were either carried out in September and October $(1979,1987)$, or in October and November (1995), and the election occurred in October in each year, we code all interviews in those years as occurring in October. The results are not sensitive to these coding decisions. Limiting the sample to years when the language of the interview was recorded reduces our sample by 9 percent but has almost no effect on the estimated coefficients for political interest. Similarly, if we recode the month of the interview for the 1979,1987 , and 1995 surveys to the other possible candidate, we obtain practically identical results.

9 Because we are using a logarithmic transformation we also recoded the months since the election to take a value of 1 (instead of 0 ) for the respondents who were interviewed during the month of an election in the neighboring country or in the month prior to an election in a neighboring country. Recoding months since election for respondents interviewed the month prior to the foreign election back to the original value has no substantive impact on the results. 


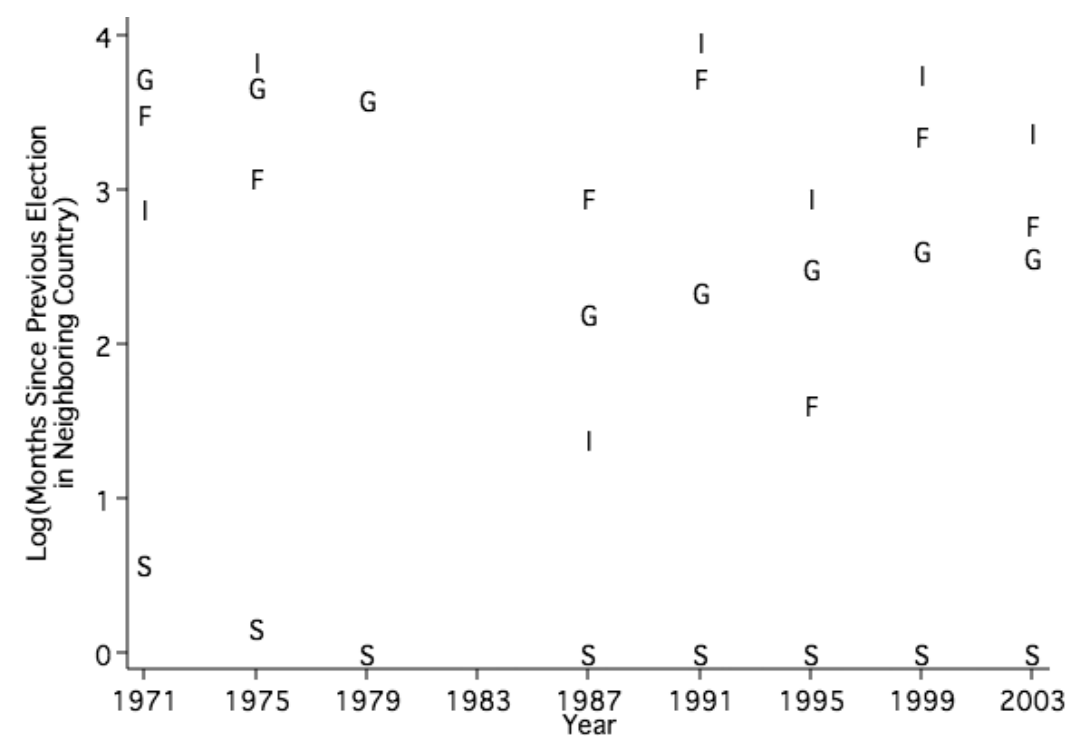

Figure 1. Average value of instrument by linguistic region each election year.

Notes: The $y$-axis is the average value of the instrumental variable, Log(Months since election), for the individuals in that region that year. The labels correspond to the three different major linguistic regions: $\mathrm{F}=$ French-speaking, $\mathrm{G}=$ German-speaking, and $\mathrm{I}=$ Italian-speaking. The label S indicates the $\log$ (Months) since the most recent Swiss national election.

response to the question. Second, we code whether respondents identify with a party as a binary variable that takes the value 1 if the respondent did identify with a party and a 0 if they did not. Third, in all of the surveys, except 1975, respondents were asked how frequently they turned out to vote on referenda and ballot initiatives on a scale from 0 to 10 . We recode the variable self-reported participation as a continuous variable that takes the value of 0 when respondents do not participate in any of the federal referendum votes and takes the value of 1 when respondents report participating in all of them. Thus an increase of 0.1 corresponds to a 10 -percentage point increase in the rate of participation in referendum votes.

We also include control variables to help ensure that any findings are the result of the exogenous increase in political interest and not the result of demographic differences across regions or time. In other words, the conditional independence assumption is more likely to be valid after conditioning on these covariates. ${ }^{10}$ The control variables include the respondents' age and dummy variables for the respondents' gender (the variable female), their religious affiliation (the excluded category is those who responded that

10 The conclusions remain the same even if we exclude the control variables (see Appendix D of the Supplementary Materials). 
they did not belong to any religious denomination), whether there was a national Swiss election in the month they were interviewed, whether respondents achieved higher levels of education (high school, high vocational training, high vocational college, or university), whether they are married, whether they are unemployed and canton-level fixed effects. ${ }^{11}$

\section{IDENTIFICATION STRATEGY: THE SWISS NATURAL EXPERIMENT}

The key assumption of our identification strategy is that Swiss citizens are attuned to the news from the neighboring country that shares their linguistic heritage. There are three features of Swiss media markets that make this assumption credible. First, foreign stations represent over 60 percent of the Swiss TV market in each of the three linguistic regions, ${ }^{12}$ and Swiss citizens are most likely to watch media from the neighboring country that corresponds to their language (see Table 1).

Second, even when Swiss citizens watch Swiss television, they are exposed to different content depending on what language they speak. Each of Switzerland's three linguistic regions has its own network that produces its own content and broadcasts in its own language (Garitaonandia, 1993; Erk, 2003) and Swiss consumers primarily watch the media produced by their linguistic region's network (Linder, 1999). Survey results from 1998 and 1999 find that, depending on the region, between 73 and 80 percent of Swiss consumers only follow the programs produced and broadcast in their primary language (Steinman et al., 2000).

Third, journalists in each region prioritize news about their linguistic community (including news from neighboring countries) over news about other linguistic regions within Switzerland (Meier and Schanne, 1995; Kriesi et al. 1996). The priority given to news about the linguistic community is one likely reason why Downey and Koenig (2006) find that German-language Swiss newspapers (French- and Italian-language Swiss papers are not included in the study) were more likely to report on an incident between prominent politicians from Italy and Germany during a meeting of the European parliament, than newspapers from countries that are part of the European Union (Belgium, France, Netherlands, and the United Kingdom).

Our instrumental variable design also rests on the assumption that $\log$ (months since election) is correlated with political interest in a significant way. The first column of Table 2 reports the results of an OLS regression of political interest on our instrument and all the control variables included in the rest of our specifications. The coefficient for the instrument has the predicted negative sign, showing that Swiss citizens' level of political interest decreases with increasing temporal distance from the previous election in the neighboring country. In terms of magnitude, the results suggest that a Swiss citizen's level of political interest will on average be 0.15 points lower, on a scale that ranges from 1 to 4 , when the instrument increases by 1 unit (which, for example, is the

11 In 2003 when the Swiss Election Study did not code Canton of residence, we use the canton where the respondent was registered to vote.

12 Source: Federal Office of Statistics (BFS) for Switzerland. 


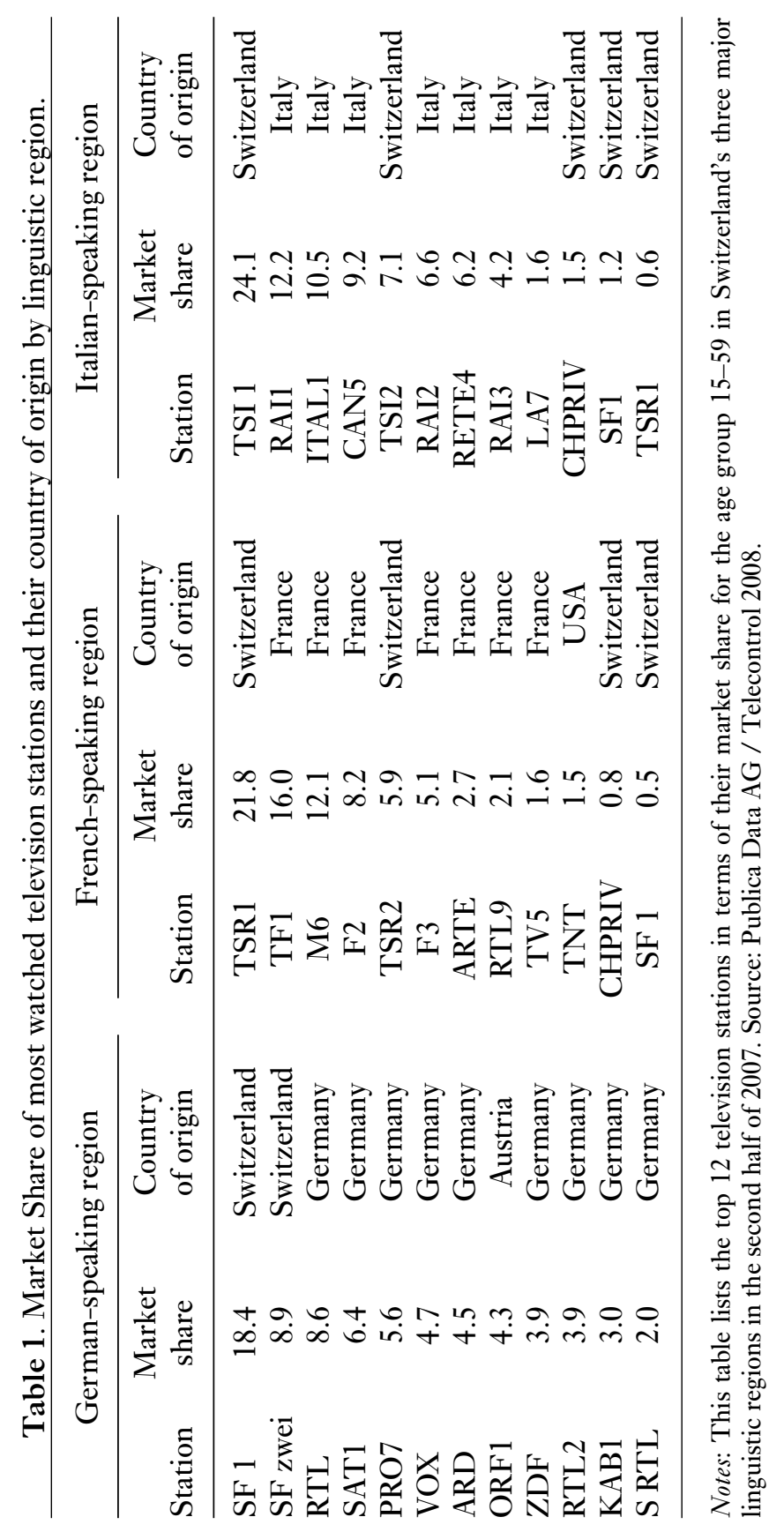


Table 2. First-stage estimates and tests of the validity of the instrumental variable research design.

\begin{tabular}{lcccc}
\hline Outcome variable: & $\begin{array}{c}\text { Political } \\
\text { interest }\end{array}$ & $\begin{array}{c}\text { Political } \\
\text { interest }\end{array}$ & $\begin{array}{c}\text { Political } \\
\text { knowledge }\end{array}$ & $\begin{array}{c}\text { Political } \\
\text { interest }\end{array}$ \\
\hline Log (Months Since Election) & -0.15 & -0.16 & -0.01 & -0.05 \\
& $(0.02)$ & $(0.02)$ & $(0.01)$ & $(0.03)$ \\
Log(Months since election & & -0.03 & & \\
-Different language) & & $(0.02)$ & & \\
Month of Swiss election & 0.17 & 0.16 & 0.06 & 0.15 \\
& $(0.02)$ & $(0.02)$ & $(0.01)$ & $(0.02)$ \\
Female & -0.28 & -0.27 & -0.16 & -0.25 \\
& $(0.02)$ & $(0.02)$ & $(0.008)$ & $(0.02)$ \\
Age & 0.008 & 0.008 & 0.0009 & 0.008 \\
& $(0.0004)$ & $(0.0004)$ & $(0.0002)$ & $(0.0004)$ \\
Higher education & 0.42 & 0.42 & 0.14 & 0.36 \\
& $(0.02)$ & $(0.02)$ & $(0.006)$ & $(0.02)$ \\
Married & 0.06 & 0.06 & 0.04 & 0.06 \\
& $(0.01)$ & $(0.01)$ & $(0.006)$ & $(0.02)$ \\
Protestant & -0.10 & -0.11 & 0.05 & -0.06 \\
& $(0.03)$ & $(0.03)$ & $(0.01)$ & $(0.03)$ \\
Catholic & -0.11 & -0.11 & 0.04 & -0.06 \\
& $(0.03)$ & $(0.03)$ & $(0.01)$ & $(0.04)$ \\
Other religion & -0.05 & -0.05 & -0.01 & -0.02 \\
& $(0.04)$ & $(0.04)$ & $(0.02)$ & $(0.04)$ \\
Unemployed & -0.20 & -0.19 & -0.07 & -0.25 \\
& $(0.07)$ & $(0.07)$ & $(0.02)$ & $(0.07)$ \\
Canton fixed effects? & Yes & Yes & Yes & Yes \\
Observations & 22,399 & 22,399 & 16,497 & 16,471 \\
Number of clusters & 189 & 189 & 77 & 77 \\
R-squared & 0.15 & 0.15 & 0.17 & 0.13 \\
F-Stat., instrument & 41.7 & & & \\
p-Value, instrument & $<0.0001$ & & & \\
\hline
\end{tabular}

Notes: Robust clustered standard errors in parentheses (where we cluster on the combination of the respondent's canton and the year they take the survey). Column 1 presents the estimates from the first-stage. Columns 2-4 present different test of the validity of the IV design. The data used in the analysis comes from the Swiss National Election Studies cumulative file (Fontana et al., n.d.).

difference between the value of the instrument 5 months after an election and 12 months after an election). The $F$-statistic for the instrument is 41.7 and significant at the 0.0001 level, which suggests that the instrument is not weak (Staiger and Stock, 1997; Stock and Yogo, 2002). 
The argument behind our identification strategy also implies that elections in neighboring nations that do not share the respondent's language should not affect the respondent's level of political interest. We create the variable log (months since electiondifferent language), which is the logarithmic transformation of the number of months since the most recent election in the two neighboring countries that do not share the respondent's language (e.g., for German-speaking Swiss: France and Italy), and compare the predictive power of this variable relative to our instrument. The second column of Table 2 presents this result. The timing of elections in the neighboring nation that shares the respondent's language still strongly predicts their level of political interest, but the timing of elections in the countries that do not share the respondent's language does not predict the respondent's level of political interest. The variable log(months since election - different language) is statistically insignificant and has a coefficient almost six times smaller than our instrument.

For our design to be valid, the instrument also needs to be independent (i.e., randomly assigned conditional on $\mathrm{X}$ ) and the exclusion restriction must hold (i.e., the instrument must have no independent effect on the outcome). In the case of independence, one possible concern is that the social, political, and economic differences among Swiss linguistic regions explain the change in outcome variables under study. For the main analysis we include canton fixed effects and several of the respondents' demographics in order to ameliorate this concern.

In terms of the exclusion restriction, there are two reasons to believe that our instrument is uncorrelated with unobservable factors determining the dependent variables. ${ }^{13}$ First, because the timing of Swiss federal elections is not subject to government manipulation, occurring in October every four years, our design is not compromised by endogeneity in the form of government officials choosing election times based on their constituents' level of political interest.

Second, the exogenous increase in the political content of the news that we identify is non-Swiss specific and therefore should not increase respondents' political knowledge. We test this assumption by creating the variable political knomledge, which gives the proportion of the knowledge questions that the respondent answered correctly, and regressing this variable on the instrument (see Column 3 of Table 2). Because the political knowledge questions were only asked in three years of the survey $(1995,1999$, and 2003), we also regress political interest on the instrument when restricting the sample

13 Although we cannot test whether the exclusion restriction holds, we did conduct the sensitivity analysis suggested by Conley et al. (2008) that allows the instrument to have a direct effect on the outcome variable in order to find out how large that direct effect could become before the results were no longer informative about the null hypothesis. Implementing what Conley et al. (2008) refer to as the support-restriction-only approach, we found that once the magnitude of the instrument's direct effect is allowed to be about 6 percent of the magnitude that we estimate for the political interest variable, the results are no longer statistically significant. In practical terms, this suggests that while there is some small room for error, any substantial violations of the exclusion restriction would make it so that we would fail to reject the null hypothesis for the tests we present. We believe that our study meets that stringent standard, however, each reader should bear this in mind when evaluating our results. 
to those years (see Column 4 of Table 2) in order to ensure that any null finding was not driven simply by the change in sample. While the predicted effect of the instrument on political interest is smaller when restricting the sample to those three years (compare Column 4 with Column 1), it continues to be statistically significant at the 10 percent level (two-sided $p$-value $<0.07$ ). By contrast, the coefficient for the instrument when predicting respondent's political knowledge is near to zero and is statistically insignificant (two-sided $p$-value $=0.39$ ). These results increase our confidence that we are actually capturing the causal effect of interest rather than an unobserved increase in political information about Swiss politics.

\section{RESULTS FROM THE INDIVIDUAL-LEVEL SURVEY DATA}

Table 3 presents, side-by-side, the OLS/probit estimates and the IV estimates. All models include the same set of controls as described above with the dependent variable listed at the top of the column. Columns 2, 4, and 6 in Table 3 present the IV estimates where the variable $\log$ (months since election) is used to instrument for political interest. Turning first to the effect of political interest on the timing of a respondent's vote decision, the IV estimate shows that an increase in the level of political interest decreases rather than increases (as suggested by the probit model) the probability that respondents report that they knew all along which party they would vote for. This estimate is significant at the 1 percent level and the magnitude of the effect is quite large. For example, individuals who are rather interested in politics are estimated to be about 30 percentage points less likely to say that they knew all along which party they would vote for relative to those who are rather not interested in politics.

In the case of party attachment (see Column 4 of Table 3 ), the IV estimate suggests that media-driven political interest reduces rather than increases the likelihood that a respondent identifies with a party. The possible influence that partisanship has on overall political interest (i.e., reverse causation) is one likely reason for the sign switch. While no one has looked specifically at the causal effect of partisanship on political interest, recent work has found that partisanship has a large effect on related attitudes and behaviors (Gerber $e t$ al., forthcoming). The magnitude of the effect of political interest on party identification is substantial. The estimated marginal effect, when holding all other variables at their mean value, suggests that going from being not at all interested in politics to being rather not interested in politics decreases the likelihood of identifying with a party by about 20 percentage points. For Party ID and Knem Vote All Along, the predicted probabilities based on the IV Probit estimates are monotonically and approximately linearly decreasing in ordered categories of Political Interest, moving from 0.84 to 0.22 in the case of Party ID, and from 0.95 to 0.22 for Knem Vote All Along (when holding other variables constant at their means). Together these findings show that an increase in media-driven political interest makes citizens significantly more open to persuasion.

Finally, Column 6 in Table 3 presents the IV estimates of the effect of political interest on self-reported participation. The IV estimate of the coefficient is still statistically significant but is now larger than the OLS estimate (Column 5). The larger magnitude 
Table 3. OLS/ probit and 2SLS estimates of the effects of media-driven political interest.

\begin{tabular}{|c|c|c|c|c|c|c|}
\hline \multirow{2}{*}{$\begin{array}{l}\text { Outcome variable: } \\
\text { Independent variable }\end{array}$} & \multicolumn{2}{|c|}{$\begin{array}{l}\text { Knew vote } \\
\text { all along }\end{array}$} & \multicolumn{2}{|c|}{$\begin{array}{l}\text { Identify } \\
\text { with party }\end{array}$} & \multicolumn{2}{|c|}{$\begin{array}{l}\text { Self-reported } \\
\text { participation }\end{array}$} \\
\hline & Probit & IV & Probit & IV & OLS & IV \\
\hline Political interest & $\begin{array}{c}0.12 \\
(0.03)\end{array}$ & $\begin{array}{c}-0.93 \\
(0.19)\end{array}$ & $\begin{array}{c}0.47 \\
(0.02)\end{array}$ & $\begin{array}{c}-0.77 \\
(0.07)\end{array}$ & $\begin{array}{l}0.17 \\
(0.004)\end{array}$ & $\begin{array}{c}0.36 \\
(0.06)\end{array}$ \\
\hline $\begin{array}{l}\text { Month of Smiss } \\
\text { election }\end{array}$ & -0.14 & 0.05 & -0.17 & 0.16 & 0.03 & -0.01 \\
\hline & $(0.06)$ & $(0.05)$ & $(0.07)$ & $(0.04)$ & $(0.01)$ & $(0.01)$ \\
\hline Female & $\begin{array}{c}-0.17 \\
(0.03)\end{array}$ & $\begin{array}{c}-0.31 \\
(0.02)\end{array}$ & $\begin{array}{c}-0.14 \\
(0.02)\end{array}$ & $\begin{array}{c}-0.35 \\
(0.02)\end{array}$ & $\begin{array}{c}-0.016 \\
(0.006)\end{array}$ & $\begin{array}{c}0.03 \\
(0.02)\end{array}$ \\
\hline Age & $\begin{array}{c}0.005 \\
(0.001)\end{array}$ & $\begin{array}{c}0.009 \\
(0.0008)\end{array}$ & $\begin{array}{c}0.004 \\
(0.001)\end{array}$ & $\begin{array}{l}0.01 \\
(0.001)\end{array}$ & $\begin{array}{c}0.001 \\
(0.000)\end{array}$ & $\begin{array}{r}-0.0003 \\
(0.0005)\end{array}$ \\
\hline Higher education & $\begin{array}{c}-0.11 \\
(0.03)\end{array}$ & $\begin{array}{c}0.23 \\
(0.07)\end{array}$ & $\begin{array}{c}0.08 \\
(0.03)\end{array}$ & $\begin{array}{c}0.48 \\
(0.03)\end{array}$ & $\begin{array}{l}0.05 \\
(0.005)\end{array}$ & $\begin{array}{c}-0.03 \\
(0.03)\end{array}$ \\
\hline Married & $\begin{array}{c}0.06 \\
(0.03)\end{array}$ & $\begin{array}{c}0.01 \\
(0.03)\end{array}$ & $\begin{array}{c}0.19 \\
(0.03)\end{array}$ & $\begin{array}{c}0.16 \\
(0.02)\end{array}$ & $\begin{array}{c}0.07 \\
(0.01)\end{array}$ & $\begin{array}{c}0.06 \\
(0.01)\end{array}$ \\
\hline Protestant & $\begin{array}{c}0.01 \\
(0.04)\end{array}$ & $\begin{array}{c}-0.13 \\
(0.04)\end{array}$ & $\begin{array}{c}0.23 \\
(0.04)\end{array}$ & $\begin{array}{c}0.01 \\
(0.04)\end{array}$ & $\begin{array}{l}0.02 \\
(0.008)\end{array}$ & $\begin{array}{c}0.04 \\
(0.01)\end{array}$ \\
\hline Catholic & $\begin{array}{c}-0.01 \\
(0.04)\end{array}$ & $\begin{array}{c}-0.13 \\
(0.05)\end{array}$ & $\begin{array}{c}0.19 \\
(0.05)\end{array}$ & $\begin{array}{c}-0.01 \\
(0.05)\end{array}$ & $\begin{array}{l}0.02 \\
(0.008)\end{array}$ & $\begin{array}{c}0.03 \\
(0.01)\end{array}$ \\
\hline Other religion & $\begin{array}{c}-0.01 \\
(0.08)\end{array}$ & $\begin{array}{c}-0.05 \\
(0.06)\end{array}$ & $\begin{array}{c}0.01 \\
(0.06)\end{array}$ & $\begin{array}{r}-0.04 \\
(0.05)\end{array}$ & $\begin{array}{c}-0.01 \\
(0.02)\end{array}$ & $\begin{array}{c}-0.004 \\
(0.02)\end{array}$ \\
\hline Unemployed & $\begin{array}{l}-0.36 \\
(0.11)\end{array}$ & $\begin{array}{l}-0.30 \\
(0.13)\end{array}$ & $\begin{array}{r}-0.20 \\
(0.10)\end{array}$ & $\begin{array}{l}-0.29 \\
(0.09)\end{array}$ & $\begin{array}{c}-0.01 \\
(0.02)\end{array}$ & $\begin{array}{c}0.03 \\
(0.03)\end{array}$ \\
\hline $\begin{array}{l}\text { Canton fixed } \\
\text { effects? }\end{array}$ & Yes & Yes & Yes & Yes & Yes & Yes \\
\hline Observations & 12,977 & 12,977 & 21,856 & 21,856 & 19,962 & 19,962 \\
\hline $\begin{array}{c}\text { Number of } \\
\text { clusters }\end{array}$ & 164 & 164 & 189 & 189 & 165 & 165 \\
\hline
\end{tabular}

Notes: Robust clustered standard errors in parentheses (where we cluster on the combination of the respondent's canton and the year they take the survey). Columns 1, 3, and 5 present OLS and Probit estimates of the effect of political interest. Columns 2, 4, and 6 present the IV estimates of the effect of political interest instrumented by $\log$ (Months Since Election). The data used in the analysis comes from the Swiss National Election Studies cumulative file (Fontana et al., n.d.).

of the IV estimate could be the result of unobserved characteristics that are positively correlated with political interest, but negatively correlated with participation. In terms of the size of the effect, the estimate implies that a one-unit increase on the political interest scale increases the number of popular ballots a respondent reported participating in by about 3.6. 
Collectively, the empirical findings in this section show that media-driven political interest benefit democracy by increasing the electorate with voters that are more independent and open to persuasion. However, the result on self-reported turnout, like all turnout results that come from survey data, is prone to social desirability bias (Traugott and Katosh, 1979; Silver et al., 1986). Moreover, the survey does not allow us to decompose self-reported turnout to make sure that the effect of media-driven political interest holds not only for referenda on international issues but also for referenda on issues least related to neighboring country politics. To address these concerns in the following section we examine the effect of our instrument on aggregate-level turnout.

\section{RESULTS USING AGGREGATE-LEVEL TURNOUT}

Table 4 displays regressions of canton-level turnout, as reported by the Swiss government, ${ }^{14}$ on the $\log$ (months since election), the number of referenda on the ballot, and canton and year fixed effects for subsets of Election-Day ballots. ${ }^{15}$ Column 1 limits the sample to ballots with referenda that included only domestic issues such as the welfare state, labor laws, political rights, and social issues. We also included army-related referenda of a domestic character, such as the abolition of cantonal jurisdiction over

Table 4. Reduced form regression of actual turnout in national referenda.

\begin{tabular}{|c|c|c|c|c|}
\hline \multirow{2}{*}{$\begin{array}{c}\mathrm{DV}=\text { canton-level turnout } \\
\text { Independent variable }\end{array}$} & \multicolumn{2}{|c|}{ All referenda } & \multicolumn{2}{|c|}{ Excluding military issues } \\
\hline & Domestic & International & Domestic & International \\
\hline \multirow{2}{*}{$\begin{array}{l}\text { Log }(\text { Months } \\
\quad \text { Since Election })\end{array}$} & -0.007 & -0.005 & -0.007 & -0.006 \\
\hline & $(0.002)$ & $(0.003)$ & $(0.002)$ & $(0.003)$ \\
\hline \multirow{2}{*}{$\begin{array}{l}\text { Number of issues } \\
\text { on ballot }\end{array}$} & -0.0004 & -0.045 & 0.002 & -0.05 \\
\hline & $(0.001)$ & $(0.003)$ & $(0.002)$ & $(0.003)$ \\
\hline $\begin{array}{l}\text { Canton and year } \\
\text { fixed effects? }\end{array}$ & Yes & Yes & Yes & Yes \\
\hline Observations & 1,570 & 900 & 1,414 & 796 \\
\hline$R$-squared & 0.60 & 0.68 & 0.64 & 0.70 \\
\hline
\end{tabular}

Notes: All of the models were estimated using OLS regression models and include canton and year fixed effects. The data used in the analysis comes from the Federal Chancellery of the Swiss government (http://www.admin.ch/ch/d/pore/va/vab_2_2_4_1.html).

14 Source: http://www.admin.ch/ch/d/pore/va/vab_2_2_4_1.html

15 We present our coding of the referenda used in this analysis in Appendix $\mathrm{E}$ of the Supplementary Materials. 
the personal equipment of army members, and referenda related to the abolition of the Swiss army in this sample. Column 2 uses the sample of ballots that included at least one referendum on an international issue such as trade, immigration, or relations with international organizations such as the United Nations or the European Community. In this column, we also included army-related votes of an international character such as peacekeeping operations by Swiss troops. Columns 3 and 4 include the same domestic and international ballots as Columns 1 and 2 except that they exclude ballots where our coding decision regarding an army related ballot could have affected how the variable was coded (i.e., we exclude all ballots with an army-related referendum that have no referenda on other international issues). Estimates in Columns 3 and 4 ensure that our coding decisions regarding army-related referenda did not drive the results (see Appendix for more details on the coding).

The behavior of Swiss voters does not depend on whether the referenda cover international or domestic issues; in both cases, the further away from the most recent election in the neighboring country (which decreases the level of interest in politics), the lower the level of turnout for the referenda election. For example, if we compare the turnout in two Swiss referenda elections - one that occurred the month after an election in the neighboring country and one that occurred a year after an election in the neighboring country - the turnout is predicted to be about 0.75 percentage points lower in the election that occurred a year later. Although these estimates are statistically significant at conventional levels, their magnitude is lower than you would expect based on the survey results. One reason the aggregate results are smaller than the results based on the individual-level survey data, which suggest that a one-unit increase in political interest increases turnout by 36 percentage points, is that the canton-level results are not accounting for the modest changes in political interest. The first-stage regression suggests that a one-unit increase in $\log$ (months since election) increases political interest by 0.15 points (see Table 2). If we use that first-stage estimate, the aggregate-level results suggest that increasing political interest by one unit would increase turnout by 4.7 percentage points $(0.7 / 0.15=4.7)$. Another reason why the aggregate estimate is still lower than the estimate based on the survey-level data is that respondents over report their participation in politics (the average self-reported turnout in the Swiss Election Study is over 70 percent even though the average of the actual aggregate-level turnout is only 44 percent). Yet, these results confirm that our research design captures a real effect. The drop in interest in politics that comes with the passage of time after an election in a neighboring country leads to a noticeable change in individuals' political behavior.

\section{DISCUSSION}

An individual's level of political interest is the result of many factors such as their upbringing, their education, their media consumption, and so forth. In this study, we exploit a natural experiment that occurs in Switzerland to identify the causal effect of political interest that varies with the political content of news. We show that increases in the level of media-driven political interest cause individuals to be more likely to turn 
out in elections, less likely to be partisan, and more likely to take more time in making vote decisions. This is good news and suggests that political events and candidates that heighten political interest are likely to benefit democracy. Perhaps even more importantly, it suggests that efforts by political practitioners to increase the amount of political news that individuals are exposed to (Lupia and Philpot, 2005) have a real and beneficial impact that extends into citizens' political attitudes and behaviors. Indeed, one concern for modern democracies is the negative impacts of the high level of apathy toward politics among their citizenry (Dalton, 2004, 2008). Our results suggest that increasing the level of political news that individuals are exposed to could help to reverse some of this apathy.

More generally, our results join a growing literature that demonstrates that people are affected by what they read and see (Ladd and Lenz, 2009; Kern and Hainmueller, 2009). This article suggests that the relationship between individuals' media consumption and their preferences is not simply the result of self-selection; media, at least in some cases, does shape individuals' political attitudes and decisions.

While this study uses data from Switzerland, there are several ways that this type of natural experiment might be exported to other contexts to study the causal effect of media-driven political interest. First, one obvious possibility is to look at other multilingual countries that are likely to share their media markets with neighboring countries such as Luxembourg, Belgium, and the Czech Republic. Second, one might look at former colonies where two colonizing nations' languages are still official, such as Cameroon, Rwanda, or Equatorial Guinea, to see whether elections in the former colonizing nation have the same impact on political interest as we describe here. Third, given that the US media is often viewed worldwide, one might look at the effect of US elections on political interest in other countries.

In this particular study, data limitations in terms of which questions were consistently asked over time narrowed the political attitudes and behaviors we could effectively study. However, by exporting this basic research design to some of the contexts given above, more light could be shed into the way media-driven political interest shapes political attitudes and behavior. Finally, the research design in this paper seems ripe for studying how the content of the news affects citizens' preferences, attitudes, and behavior.

\section{REFERENCES}

Aldrich, J. H. 1993. "Rational Choice and Turnout." American Fournal of Political Science 37(1): $246-278$.

Ansolabehere, S., E. C. Snowberg, and J. M. Snyder, Jr. 2006. "Television and the Incumbency Advantage in U.S. Elections." Legislative Studies Quarterly 31(4): 469-490.

Arellano, M. 1987. "Computing Robust Standard Errors for Within-Group Estimators." Oxford Bulletin of Economics and Statistics 49(4): 431-434.

Baum, M. 2002. "Sex, Lies and War: How Soft News Brings Foreign Policy to the Inattentive Public." American Political Science Reviem 96(March): 1.

Benz, M. and A. Stutzer. 2004. "Are Voters Better Informed When They Have a Larger Say in Politics?: Evidence for the European Union and Switzerland." Public Choice 119(1/2): 31-59.

Berelson, B. R., P. Lazarsfeld, and W. M. McPhee. 1954. Voting. Chicago: University of Chicago Press. 
Campbell, A., P. E. Converse, W. E. Miller, and D. E. Stokes. 1960. The American Voter, New York: John Wiley \& Sons, Inc.

Conley, T. G., C. Hansen, and P. E. Rossi. 2008. "Plausibly Exogenous." Working Manuscript (July 31, 2008). Available at SSRN: http://ssrn.com/abstract $=987057$.

Dalton, R. J. 2004. Democratic Challenges, Democratic Choices: The Erosion of Political Support in Advanced Industrial Democracies. New York: Oxford University Press.

Dalton, R. J. 2008. Citizen Politics: Public Opinion and Political Parties in Advanced Industrial Democracies, 5 th ed. Washington, DC: CQ Press.

Downey, J. and T. Koenig. 2006. "Is There a European Public Sphere? The Berlusconi-Schulz Case." European Fournal of Communication 21(2): 165-187.

Dunning, T. 2008. "Model Specification in Instrumental-Variables Regression.” Political Analysis 16(3): $290-302$.

Erk, J. 2003. "Swiss Federalism and Congruence." Nationalism and Ethnic Politics 9(2): 50-74.

Fontana, M.-C., P. Selb, and R. Lachat: n.d. Electoral Surveys in Switzerland - 1971-2003 (Cumulative dataset). Production: SIDOS, Swiss Information and Data Archive Service for the Social Sciences, Neuchâtel. Distributed by SIDOS.

Garitaonandia, C. 1993. "Regional Television in Europe." European Fournal of Communication 8(3): 277-294.

Gentzkow, M. 2006. “Television and Voter Turnout." The Quarterly Fournal of Economics 121(3): 931-972.

Gerber, A. S., G. A. Huber, and E. Washington. Forthcoming. "Party Affiliation, Partisanship, and Political Beliefs: A Field Experiment.” American Political Science Reviem.

Gopoian, J. D. and S. Hadjiharalambous. 1994. "Late-deciding Voters in Presidential Elections." Political Behavior 16(1): 55-78.

Hinich, M. J. 1981. "Voting as an Act of Contribution.” Public Choice 36: 135-140.

Kern, H. L. and J. Hainmueller. 2009. "Opium for the Masses: How Foreign Free Media Can Stabilize Authoritarian Regimes.” Political Analysis 17: 377-399.

Kriesi, H., B. Wernli, P. Sciarini, and M. Gianni. 1996. Le Clivage Linguistique. Problemes de Comprehension entre les Communautes Linguistiques en Suisse. Berne, Suisse: Office Federal de la Statistique.

Lacy, D. and B. C. Burden. 1999. "The Vote-Stealing and Turnout Effects of Ross Perot in the 1992 U.S. Presidential Election." American fournal of Political Science 43(1): 233-255.

Ladd, J. M. and G. S. Lenz. 2009. "Exploiting a Rare Communication Shift to Document the Persuasive Power of News Media.” American Fournal of Political Science 53(2): 394-410.

Linder, W. 1999. "Politische Kultur." In Handbuch der Schmeizer Politik/Manuel de la Politique Suisse, eds. U. Kloti, P. Knoepfel, H. Kriesi, W. Linder, and Y. Papadopoulos, Zurich, Schweiz: Verlag Neue Zurcher Zeitung.

Livingstone, S. and T. Markham. 2008. "The Contribution of Media Consumption to Civic Participation." British Fournal of Sociology 59(2): 351-371.

Lupia, A. and T. S. Philpot. 2005. "Views from Inside the Net: How Websites Affect Young Adults' Political Interest." Fournal of Politics 67(4): 1122-1142.

Mansbridge, J. 1999. “On the Idea that Participation Makes Better Citizens.” In Citizen Competence and Democratic Institutions, eds. S. L. Elkin and K. E. Soltan. University Park, PA: Penn State Press, pp. 291-325.

Marcus, G. E. and M. B. MacKuen. 1993. "Anxiety, Enthusiasm, and the Vote: The Emotional Underpinnings of Learning and Involvement During Presidential Campaigns." American Political Science Reviem 87: 672-685.

Martin, P. 2008. "The Mass Media as Sentinel: Why Bad News about Issues is Good News for Participation." Political Communication 25: 180-193.

McCombs, M. E. and D. L. Shaw. 1972. "The Agenda-Setting Function of Mass Media." Public Opinion Quarterly 36(2): 176-187.

Meier, W. A. and M. Schanne. 1995. La Paysage Mediatique Suisse, Zurich, Suisse: Pro Helvetia.

Meredith, M. and N. Malhotra. 2010. "The Effect of Early Voting on Election Outcomes: Implications for Public Policy and the Study of Momentum in Congress.” Working Paper. University of Pennsylvania. 
Popkin, S. L. 1991. The Reasoning Voter: Communication and Persuasion in Presidential Campaigns. Chicago: University of Chicago Press.

Silver, B. D., B. A. Anderson, and P. R. Abramson. 1986. "Who Overreports Voting?” American Political Science Reviem 80(2): 613-624.

Sniderman, P. M., R. A. Brody, and P. E. Tetlock. 1991. Reasoning and Choice: Explorations in Political Psychology. New York: Cambridge University Press.

Snyder, J. M., Jr. and D. Strömberg. Forthcoming. "Press Coverage and Political Accountability." Fournal of Political Economy.

Staiger, D. and J. H. Stock. 1997. "Instrumental Variables Regression with Weak Instruments.” Econometrica 65(May): 557-586.

Steinman, M., S. Zaugg, and R. Gattlen. 2000. Medien und Idenitat: Eine Studie Zum Beitrag von Radio und Fernehprogrammen zur gesellischaftlichen und kulturellen Intgration in der Schweiz. Bern, Schweiz: SRG/SSR.

Stock, J. H. and M. Yogo. 2002. "Testing for Weak Instruments in Linear IV Regression." NBER Working Paper No. T0284. Available at SSRN: http://ssrn.com/abstract=346941.

Stromback, J. and A. Shehata. 2010. "Media Malaise or a Virtuous Circle? Exploring the Causal Relationship between News Media Exposure, Political News Attention and Political Interest." European Fournal of Political Research 49: 575-597.

Traugott, M. W. and J. P. Katosh. 1979. "Response Validity in Surveys of Voting Behavior." Public Opinion Quarterly 43(3): 359-377.

Verba, S., K. Schlozman, and H. E. Brady. 1995. Voice and Equality: Civic Voluntarism in American Politics. Cambridge, MA: Harvard University Press.

White, H. 1984. Asymptotic Theory for Econometricians. San Diego, CA: Academic Press.

Zaller, J. R. 1998. "Monica Lewinsky's Contribution to Political Science.” PS: Political Science and Politics 31(2): 182-189. 